\title{
Sistem Pendidikan Pesantren Dalam Membangun Karakter Berbangsa dan Bernegara
}

\author{
Soleha \\ Pascasarjana \\ IAIN Syaikh Abdurrahman Siddik Bangka Belitung \\ Bangka, Indonesia \\ soleha215x@gmail.com
}

\begin{abstract}
Islamic boarding school as a native educational institution of Indonesia, has a dynamic education system. Implementation of the education system grows and builds the values of character in the nation and state. This can be proven; the life process built in Islamic boarding school contains the value of togetherness, democracy, mutual respect and tolerance among each other. This sense of togetherness and mutual respect are the foundation of the diversity of Indonesian. This condition can be established because the value of Pancasila (Five Principals) as a reflection in living life in boarding school has been implemented there for years. But now, Islamic boarding school is facing the modernization in the education system. But this change due to modernization will not diminish the value of native boarding school since the it has the elements such us Islamic scholars, the students of Islamic boarding school itself, the Quranic Yellow Book and mosques become the central of education which are deeply rooted in the system of education itself.
\end{abstract}

Keywords: Islamic education system, nation character buiding

\begin{abstract}
Abstrak
Pesantren sebagai lembaga pendidikan asli Indonesia, memiliki sistem pendidikan yang dinamis. Pelaksanaan sistem pendidikannya menumbuhkan dan membangun nilai-nilai karakter dalam berbangsa dan bernegara. Ini dapat dibuktikan, proses kehidupan yang dibangun di pesantren terkandung nilai kebersamaan, demokrasi, saling menghargai dan toleransi antara sesamanya. Rasa kebersamaan dan saling menghargai ini lah yang menjadi pondasi dari keberagaman bangsa Indenesia. Kondisi ini bisa terjalin karena di pondok pesantren memiliki panca jiwa sebagai refleksi dalam menjalani kehidupan di pondok pesantren. Menghadapi modernisasi pesantren mengalami "perubahan" dalam sistem pendidikannya. Namun perubahan ini tidak memudarkan kecirikhasan pondok pesantren. Karena unsur di dalamnya yang terdiri dari kiai, santri, kitab kuning serta masjid yang menjadi sentral pendidikannya sangat mengakar dalam sistem pendidikannya. Dalam menghadapi modernisasi pesantren mengalami "perubahan" dalam sistem pendidikannya. Namun perubahan ini tidak memudarkan kecirikhasan pondok pesantren. Karena unsur di dalamnya terdiri dari kiai, santri, kitab kuning serta masjid yang menjadi sentral pendidikannya sangat mengakar dalam sistem pendidikannya.
\end{abstract}

Kata Kunci: sistem pendidikan pesantren karakter bangsa 


\section{A. Pendahuluan}

Secara historis, pesantren telah " mendokumentasikan" berbagai peristiwa sejarah bangsa Indonesia, baik dari sejarah sosial budaya masyarakat Islam, ekonomi, maupun politik bangsa Indonesia. Menurut Hanun Asrorah, sejak masa awal penyebaran Islam ${ }^{1}$, pesantren adalah saksi utama bagi penyebaran Islam di Indonesia, karena pesantren merupakan sarana penting bagi kegiatan islamisasi di Indonesia. Perkembangan dan kemajuan masyarakat Islam Nusantara (khususnya Jawa) tidak mungkin terpisahkan dari peranan penting pesantren. Besarnya arti pesantren dalam perjalanan bangsa Indonesia, khususnya di Jawa, tidak berlebihan jika pesantren dianggap sebagai bagian historis bangsa Indonesia yang harus dipertahankan. Apalagi, pesantren sudah dianggap sebagai lembaga pendidikan asli Indonesia yang mengakar kuat dari masa pra-Islam, yaitu lembaga pendidikan bentuk asrama, yang diadopsi dari agama Budha—mandala ata asyrama-yang ditransfer menjadi lembaga pendidikan Islam. ${ }^{2}$

Pesantren sebagai lembaga tertua di Indonesia memiliki peranan yang sangat penting dalam pembinaan karakter bangsa. Keunikan yang dimiliki pesantren dalam sistem pembinaan dan pembelajarannya, membuat pesantren tidak habis-habisnya untuk dibahas bahkan sebagai kajian penelitian. Dalam sistem kelembagaan yang dijalankannya ada yang menggunakan sistem salafi dan khalafi. Begitu juga dalam metode pembelajarannya memiliki variasi sesuai dengan materi yang disampaikan, sehingga dapatlah di pahami, walaupun pesantren sebagai lembaga pendidikan tradisional, namun hakekatnya mengandung nilai-nilai kemanusian dan kebersamaan secara berbangsa dan bernegara.

\section{B. Sistem Pendidikan Islam di Pondok Pesantren Sebagai Acuan Pendidikan Karakter}

Berbicara tentang sistem pendidikan Islam, maka hubungannya sangat erat dengan hakekat dan konsep manusia ${ }^{3}$ itu sendiri. Bahwa, apa yang dilakukan dalam

1 Berpusat dari pesantren, perputaran roda ekonomi dan kebijakan politik Islam dikendalikan. Di masa Wali Sanga, tidak sedikit para wali-wali di Jawa menguasai jaringan perdangangan antara pulau Jawa dengan Luar Jawa, seperti Sunan Giri yang memiliki jaringan perdagangan antara Jawa dengan Kalimantan, Maluku, Lombok dan sebagainya. Sedangkan perjalanan politik Islam di Jawa, pesantren mempunyai pengaruh yang kuat bagi pembentukan dan pengambilan berbagai kebijakan di kraton-kraton. Misalnya, dengan berdirinya kerajaan Islam Demak, adalah karena dukungan dan kontrol yang kuat dari para ulama seperti Sunan Kudus, Sunan Kalijaga dan sebagainya.Maka dapat disimpulkan dari perjalan panjang sejarah pesantren, bahwa dinamika masyarakat Islam di masa awal dapat ditandai dengan adanya hubungan yang kuat antara pesantren, pasar, dan kraton. Lebih jelas lihat Hanun Asrohah, Sejarah Pendidikan Islam, Jakarta: Logos, 1999, hal. 183.

${ }^{2}$ Ibid

${ }^{3}$ Menurut Sastraprateja sebagaimana yang dikutip oleh Ramayulis, bahwa hakekat manusia hanya dapat dilihat dalam perjalanan sejarah bangsa manusia. Lebih lanjut dikatakan bahwa apa yang kita peroleh dari pengamatan atas pengalaman manusia adalah suatu rangkaian anthropological constants, yaitu dorongan-dorongan dan orientasi yang tetap dimiliki manusia. Sekurang-kurangnya ada enam anthropological constants yang dapat ditarik dari pengalaman sejarah umat manusia, yaitu: 1) Relasi manusia dengan kejasmanian, alam dan lingkungan ekologis; 2) Ketertiban dengan sesama; 3)Keterikatan dengan struktur sosial dan internasional; 4) Ketergantungan masyarakat dan 
kehidupan manusia selalu berorientasi kepada persoalan dunia dan akherat yang selanjutnya akan menghasilkan perbuatan baik atau buruk. Menurut Ali Syari'ati manusia di pahami sebagai zat Theomorfis yang berorientasi sebagai pribadi yang bergerak di antara dua titik ekstrem "Allah-Setan". ${ }^{4}$ Dimana menurut Harun Nasution, bahwa Tuhan menciptakan potensi atau daya-daya yang ada dalam diri manusia, sedangkan perkembangan selanjutnya terserah kepada manusia. ${ }^{5}$

Sebagai lembaga pendidikan Islam yang tertua di Indonesia, pesantren memiliki ciri khas dalam menjalankan sistem pendidikannya. Sistem Pendidikan Islam yang dilaksanakan di pondok pesantren memiliki keunikan dibandingkan dengan sistem yang diterapkan dalam lembaga pendidikan pada umumnya. Keunikan dari sistem pendidikan di Pesantren menurut Menurut Amien Rais yaitu ${ }^{6}$ :

1. Memakai sistem tradisional, yang memiliki kebebasan penuh dibandingkan dengan sekolah modern, sehingga terjadi hubungan dua arah antara kiai dan santri.

2. Kehidupan di pesantren menampakkan semangat demokratis, karena mereka praktis bekerjasama mengatasi problema non kurikuler mereka sendiri.

3. Para santri tidak mengidap penyakit simbolis, yaitu perolehan gelar dan ijazah, karena sebagaian besar pesantren tidak mengeluarkan ijazah, sedangkan santri dengan ketulusan hatinya masuk pesanten tanpa adanya ijazah tersebut. Hal itu karena tujuan utama mereka hanya ingin mencari keridhoan Allah SWT semata.

4. Sistem pondok pesantren mengutamakan kesederhanaan, idealisme, persaudaraan, persamaan, rasa percaya diri, dan keberanian hidup.

5. Alumni pondok pesantren tak ingin menduduki jabatan pemerintah, sehingga mereka tidak dapat dikuasai oleh pemerintah.

Berdasarkan pemaparan yang diungkapkan oleh Amien Rais, menurut hemat penulis ada beberapa hal yang masih di pegang teguh ataupun ditinggalkan dalam sistem pendidikan di pondok pesantren. Antara lain sistem yang masih dipegang hampir diseluruh pesantren adalah tentang hubungan antara kiai dan santri. Bahwa dalam proses pendidikannya kiai tidak hanya diposisikan sebagai seorang figur yang di "tuakan" sehingga sulit untuk berinteraksi dalam segala aspek kegiatan di pondok. Namum posisi kiai disini dapat dijadikan sebagai seorang teman untuk berdiskusi, orang tua yang mengayomi dalam segala aktivitas di pondok tanpa ada ruang yang membatasinya. Namun kepatuhan dan

kebudayaan pada waktu dan tempat; 5) Hubungan timbal balik antara teori dan praktik; 6) Kesadaran relegius para pemeluk agama. Ramayulis, Ilmu Pendidikan Islam, Jakarta: Kalam Mulia, cet. X 2013, hal. 1-2.

4 Ali Syari'ati, Tentang Sosiologi Islam, Yokyakarta: Ananda, 1982, Terj. Saifullah Mahyuddin, hal. 125.

${ }^{5}$ Harun Nasution, Teologi Nasution, Aliran-aliran, Sejarah, Analisa Perbandingan, Jakarta: UI Press, 1983, hal. 102.

${ }^{6}$ M. Amien Rais, Cakrawala Islam, Antara Cita dan Fakta, Bandung: Mizan, 1989, hal. 162. 
keikhitraman seorang santri kepada kiai inilah yang menjadikan figur yang dihormati bukan ditakuti.

Selanjutnya, pemberian gelar dan ijazah di pondok pesantren bukanlah suatu keharusan. Sebagaimana wasiat yang disampaikan oleh K.H. Imam Zarkasyi, pimpinan Pondok Pesantren Modern Gontor Ponorogo bahwa nilai yang terpenting di pesantren bukanlah ijazah, namun:

1. Ilmu pribadi dan kecakapan dalam masyarakat akan membuktikan buah yang berharga dan dihargai.

2. Kenyataan hasil ilmu pribadi dan kecakapan yang berguna bagi masyarakat itulah yang sebenar-benarnya ijazah dan surat keterangan yang dipertanggungjawabkan di dunia dan akherat nanti.

3. Nilai dari pada ijazah, surat keterangan dari suatu perguruan/ pendidikan ialah atas hasil usaha bagi kebaikan manusia. ${ }^{7}$

Walaupun dalam Peraturan Pemerintah No. 13 Tahun 2015 Pasal 89 ayat 1Tentang Perubahan Kedua Atas Peraturan Pemerintah No. 9 Tahun 2015 Tentang Standar Nasional Pendidikan menerangkan bahwa, peserta didik yang lulus dari Satuan Pendidikan diberi ijazah. Hal ini untuk kondisi sekarang tidak menjadi persoalan yang serius. Karena untuk melanjutkan ke perguruan tinggi setiap calon mahasiswa diperbolehkan tanpa harus mengikuti proses penyesuaian ijazah.

Sedangkan bagi lulusan Pondok Pesantren ruang geraknya untuk berkecimpung di dunia pemerintahan dan politik saat ini terbuka sangat lebar. Dikarenakan peluang tersebut tidak membatasi dari mana pendidikan mereka berasal. Namun, dengan mengemban nama besar alumninya membuat mereka lebih menjaga amanah yang telah diembannya.

Perjalanan panjang pesantren dalam sejarah pendidikan di Indonesia, memiliki peranan penting dalam pengembangan pendidikan di Indonesia. Walaupun pesantren merupakan lembaga pendidikan Islam tradisional, akan tetapi pesantren bukan semata-mata sebagai sebuah institusi pendidikan saja. Menurut Ismail, sejak kemunculannya pesantren sebagai sebuah institusi yang telah berakar kuat di dalam masyarakat Indonesia. Pesantren merupakan produk dari sistem pendidikan pribumi yang memiliki akar sejarah, budaya dan sosial di Indonesia. ${ }^{8}$

Seiring perjalanannya, pesantren telah membuktikan dirinya sebagai suatu lembaga pendidikan Islam yang established (mapan) dan memiliki posisi strategis dalam dunia pendidikan di Indonesia. Walaupun banyak perubahan yang dialami bangsa Indonesia baik dari segi sosial, politik, budaya, namun sejauh ini tidak mempengaruhi eksistensi pesantren. Disebabkan pesantren telah memberikan sumbangan terbesar bagi pencerdasan kehidupan bangsa dan pengembangan kebudayaan masyarakat Indonesia. Hal ini juga didukung dari tiga fungsi ganda yang dimiliki oleh pesantren yaitu: pertama, sebagai lembaga pendidikan keagamaan yang berfungsi untuk menyebarluaskan dan mengembangkan ilmu-

${ }^{7}$ Imam Zarkasyi dan Ahmad Sahal, Wasiat, Pesan dan Harapan, Pendiri Pondok Modern Gontor, tt, hal. 8 .

${ }^{8}$ Ismail Sm dkk (ed), Dinamika Pesantren dan Madrasah, Yokyakarta: Pustaka Pelajar, 2002, p.xix. 
ilmu keagamaan Islam. Kedua, sebagai lembaga pengkaderan yang berhasil mencetak kader umat dan kader bangsa. Umumnya kader-kader tersebut memperoleh mengakuan sosial (social recognition) yang luas. Ketiga, berfungsi sebagai agen reformasi sosial yang menciptakan perubahan dan perbaikan dalam kehidupan bermasyarakat. Hal terakhir ini mungkin saja terjadi karena pesantren dengan figur sentral kiai ${ }^{9}$ mempunyai pengaruh yang kuat di kalangan masyarakat sekitar sehingga dapat melakukan mobilisasi yang cepat dan efektif. ${ }^{10}$

Untuk mengetahui siapa yang layak disebut kiai atau yang tidak, mestinya harus ada parameter yang jelas supaya tidak terjebak pada penggunaan gelar pada orang yang tidak pantas digelari dengan gelar tersebut. Menurut Abuddin Nata sebagaimana yang dikutib oleh Syahrul A'dam bahwa kiai secara keilmuan mempunyai ciri-ciri antara lain: (1) menguasai ilmu agama secara mendalam; (2) keilmuan yang dimiliki telah mendapat pengakuan dari masyarakat sekelilingnya; (3) menguasai kitab kuning dengan matang; (4) taat beribadah kepada Allah SWT; (5) mempunyai kemandirian dalam bersikap; (6) tidak mau "mendatangi" penguasa; (7) mempunyai geneologi ke-kiai-an; (8) memperoleh ilham dari Allah. ${ }^{11}$ Jika memenuhi kreteria tersebut, maka layaklah seseorang disebut kiai dalam pengertian yang lazim.

Perkembangan pesantren yang sangat dinamis menghasilkan berbagai ekspresi pesantren dalam kehidupan berbangsa dan bernegara, dan melahirkan ragam dan varian pesantren. Selain itu, perkembangan pesantren juga terkait dengan status dan peranannya yang semakin luas (wider mandate) dari sebagai lembaga keagamaan, pendidikan, sosial sampai ke kampung peradaban dan artefak peradaban Indonesia. Realitas perkembangan kelembagaan pesantren saat ini dihadapkan pada longgarnya definisi "pesantren", kapasitas pesantren dan tipologi pesantren seperti kategori 'salaf', 'khlaf', dan kombinasi yang selama ini sudah menjadi ketentuan baku khususnya di internal Kementerian Agama maupun praktisi pesantren. Qomar mengklasifikasikan pesantren sebagaimana yang dijelaskan oleh Husen, bahwa aspek dari kelembagaan pesantren dapat diklasifikasikan menjadi pesantren: (1) modern dan tradisional, (2) salafi dan

\footnotetext{
${ }^{9}$ Kiai adalah istilah yang berasal dari Jawa yang dipakai untuk tiga jenis gelar yang saling berbeda; Pertama, sebagai gelar kehormatan bagi barang-barang yang dianggap keramat, seperti "kiai Garuda kencana yang dipakai untuk kereta emas yang ada di keraton Yokyakarta; kedua, gelar kehormatan untuk orang-orang tua pada umumnnya; ketiga, gelar yan diberikan masyarakat kepada orang agama Islam yang memilikiatau menjadi pemimpin pesantren dan mengajarkan kitab-kitab Islam klasik kepada santrinya. Lihat Zamakhsyari Dhofier, Tradisi Pesantren: Studi tentang Pandangan Hidup Kiai, Jakarta: LP3ES, 1994, hal. 55.

${ }^{10}$ M. Din Syamsuddin, Etika Agama dalam membangun Masyarakat Madani, Jakarta: Logos Wacana Ilmu dan Pemikiran, 2000, hal. 101-102. Lihat juga Rusydi Sulaiman, Falsafah dan Idealisme Pesantren, Upaya Merevitalisasi kelembagaan Pondok Pesantren, Makalah disampaikan pada acara Workshop Pemgembangan Pemikiran keagamaan di Pessantren, tanggal 9-11 November 2016 di Aston Bangka Belitung.

${ }^{11}$ Suwito dan Fauzan (ed), Sejarah Sosial Pendidikan Islam, Jakarta: Kencana, 2005, hal. 273.
} 
khlafi, (3) sederhana, sedang dan maju, (4) kecil, menengah dan besar, (5) untuk anak-anak, orang tua, dan mahasiswa, (6) pedesaan dan perkotaan. ${ }^{12}$

Indikator dan parameter sebuah lembaga dikatakan pesantren apabila memenuhi unsur dan nilai-nilai yang selama ini disepakati oleh pesantren. Yaitu: kiai, masjid, kitab kuning, santri dan asrama/pondok. Lebih jelas K.H. Imam Zarkasy mengartikan terminologi pesantren sebagai lembaga pendidikan Islam dengan sistem asrama atau pondok, di mana kiai sebagai figur sentral, masjid sebagai pusat kegiatan yang menjiwainya, dan pengajaran agama Islam di bawah bimbingan kiai yang diikuti santri sebagai kegiatan utamanya. ${ }^{13}$ Melihat dari penjelasan di atas maka dapat disimpulkan bahwa pesantren adalah lembaga pendidikan Islam asli Indonesia yang memiliki kekhasan dalam sistem pendidikannya. Yang di dalamnya ada unsur-unsur pendukung dalam melaksanakan sistem pendidikannya yaitu: kiai, santri, kitab kuning serta masjid yang menjadi sentral pendidikannya.

Namun seiring zaman unsur-unsur pesantren harus terus bertambah sesuai dengan lajunya perkembangan kepemilikan terutama dalam bidang sarana dan prasarana. Oleh karena itu, diperlukan redefinisi pesantren dengan unsur dan nilainilai baru. Untuk itu, pesantren merepresentasikan pendidikan unik yang mensintesakan dimensi sosial, budaya dan agama. Akar dan sintesis ini kemudian mempengaruhi fungsi pesantren baik secara internal maupun eksternal.

Sedangkan keberadaan masjid mutlak harus dimiliki pesantren, sebab di masjidlah akan dilaksanaknnya proses pendidikan dalam bentuk komunikasi belajar mengajar antara kiai dan santri. Sebagai sentral pendidikan Islam yang telah berlangsung sejak masa Rasulullah, tradisi ini tetap dipegang oleh para kiai pemimpin pesantren untuk menjadikan masjid sebagai pusat pendidikan. Kendatipun pada saat sekarang pesantren telah memiliki lokal belajar yang banyak untuk tempat berlangsungnya proses belajar mengajar, namun masjid tetap difungsikan sebagai tempat belajar.

Sebagai lembaga pendidikan tradisional Islam, Pesantren merupakan wadah untuk mempelajari, memahami, menghayati, dan mengamalkan ajaran Islam dengan menekankan pentingnya moral keagamaan sebagai pedoman perilaku sehari-hari. Menurut Dhofier sistem pendidikan pesantren menggunakan pendekatan holistic. Artinya, para pengasuh pesantren memandang bahwa kegiatan belajar mengajar merupakan kesatupaduan atau lebur dalam totalitas dalam kehidupan sehari-hari. Bagi warga pesantren, belajar di pesantren tidak mengenal hitungan waktu, kapan harus memulai dan kapan harus selesai, dan target apa yang harus dicapai. Bagi warga pesantren, hanya ilmu fardlu 'ayn yang dipandang sakral sedangkan ilmu fardlu kifayah tidak. ${ }^{14}$ Lebih lanjut Mastuhu menyebutkan bahwa,

${ }^{12}$ Husen Hasan Basri, Makalah, "Kapasitas dan Tawaran "Tipologi Baru” Pesantren, disampaikan dalam acara Wokrshop Pengembangan Pemikiran Keagamaan di Pesantren, di Aston Pangkalpinang pada tanggal 9-11 November 2016.

${ }_{13}$ Amir Hamzah Wiryosukarto, et al, Biografi K.H. Imam Zarkasyi dari Gontor Merintis Pesantren Modern, Ponorogo: Gontor Press, 1996, cet. Ke-1, hal. 51.

${ }^{14}$ Zamakhsyari Dhofier, Tradisi Pesantren: Studi PandanganHidup Kyiai, Jakarta: LP3ES, hal.3. 
idealnya pengembangan kepribadian yang dituju adalah kepribadian Muslim yang kaffah, bukan sekedar Muslim biasa. ${ }^{15}$ Oleh karena itu sistem tradisional yang telah dilakukan pesantren tidak perlu ditinggalkan. Namun tetap harus menyesuaikan dengan perkembangan zaman.

Menurut Azra, para eksponen pesantren cenderung lebih hati-hati dalam menjawab perubahan di sekelilingnya. Mereka tidak tergesa-gesa mentransformasikan kelembagaan pesantren menjadi lembaga pendidikan Islam modern sepenuhnya, tetapi menerimanya dalam skala yang sangat terbatas; sebatas melakukan penyesuaian yang mereka anggap akan mendukung kontinuitas pesantren itu sendiri, seperti sistem penjenjangan, kurikulum yang lebih jelas, dan sistem klasikal. ${ }^{16}$ Oleh sebab itulah, mengapa pesantren tetap eksis sampai sekarang walaupun derasnya arus modernisasi pendidikan Islam namun tidak dapat melunturkan sistem kelembagaan pesantren. Karena jika dibandingkan dengan lembaga pendidikan Islam lainnya yaitu Surau ${ }^{17}$ semakin hari semakin berkurang jumlahnya bahkan sekarang banyak yang merubah istilah "surau" diganti dengan "pesantren".

Sesuai dengan latar belakang sejarah pesantren, maka dapat dilihat tujuan utama didirikannya suatu pesantren adalah untuk mendalami ilmu-ilmu agama (tauhid, fiqih, ushul fiqih, tafsir, hadist, akhlak, tasawuf, bahasa Arab dan lainlain). Diharapkan seorang santri setelah keluar dari pesantren telah memahami beranekaragam mata pelajaran agama dengan kemampuan merujuk kepada kitabkitab klasik. Karena tuntutan pokok yang mesti dikuasai oleh santri adalah ilmuilmu agama Islam, maka tidak boleh tidak para santri mesti memahami ilmu-ilmu agama Islam itu dari sumber aslinya, yaitu Al-Qur'an dan Sunnah yang telah dijabarkan oleh ulama-ulama terdahulu dalam kitab-kitab klasik berbahasa Arab

\footnotetext{
${ }^{15}$ Mastuhu, Dinamika Sistem Pendidikan Pesantren, Jakarta: INIS, 1994, hal. 57.

16 Azyumardi Azra, "Pesantren: Kontuinitas dan Perubahan", Pengantar dalam Nurcholis Madjid, Bilik-Bilik Pesantren: Sebuah Potret Perjalanan, Jakarta: Paramadina, 1997, hal. xiv.

${ }^{17}$ Surau dalam konteks sosial-kultural Minangkabau, bermakna sebagai tempat bermalam bagi laki-laki yang belum menikah, namun kemudian surau dijadikan sebagai institusi pendidikan oleh ulama di Minangkabau. Keterujian keulamaan seseorang di Minangkabau sangat ditentukan oleh kepemilikan surau tersebut. Seorang ulama di Minangkabau pasti memiliki surau sebagai lokus aktivitasnya. Bahkan dalam persepsi masyarakat, seorang ulama yang belum memiliki surau berarti keberadaannya sebagai seorang ulama di tengah-tengah masyarakat belum dapat diterima secara penuh. Bahkan Azyumardi Azra menyebutkan bahwa, surau Burhanuddin merupakan institusi pendidikan Islam yang tidak dapat dipisahkan dalam sejarah sosial Islam Minangkabau. Pendidikan surau yang di bangun oleh Burhanuddin ini, pada dasarnya yang merubah peta prilaku masyarakat Minangkabau. Karena pendidikan yang diterapkan oleh Burhanuddi sebagai figur ulama transformatif pertama bagi masyarakat Minangkabau tersebut, karena direkonstruksinya pendidikan akhlakul karimah berdasarkan pendekatan-pendekatan lokalitas, relejiusitas yang sangat tidak merusak khazanah masyarakat, sehingga kedatangan Islam dengan mudah merubah dimensi-dimensi sosial profan lokalitas. Lihat lebih jelas Silfia Hanani, Makalah, Surau Representasi Pondok Pesantren Tradisional dalam Membangun Intelektualitas di Minangkabau, dalam acara Wokrshop Pengembangan Pemikiran Keagamaan di Pesantren, di Aston Pangkalpinang pada tanggal 9-11 November 2016.
} 
dengan segala cabang-cabangnya adalah merupakan unsur pokok dalam suatu pesantren.

Dengan pemberian materi-materi keagamaan ini, bukan saja para santri bisa memahami isi materi kitab-kita tersebut. Namun hal yang lebih penting adalah implementasi dari materi pelajaran yang telah diterima selama di pesantren dalam kehidupan bermasyarakat. Karena sumber dari kajian kitab yang menjadi rujukan di pesantren bersumber kepada al-Qur'an dan Hadits yang merupakan sumber dari segala sumber ilmu pengetahuan. Sebagaimana yang dijelaskan oleh Baedhowi, bahwa al-Qur'an sebagaimana sumber primer ajaran Islam mengandung bahasabahasa simbolis yang kaya akan analisis-analisis tematik dan konseptual. ${ }^{18}$

Sebagaimana yang dijelaskan dalam Q.S. al-Fushshilat 53:

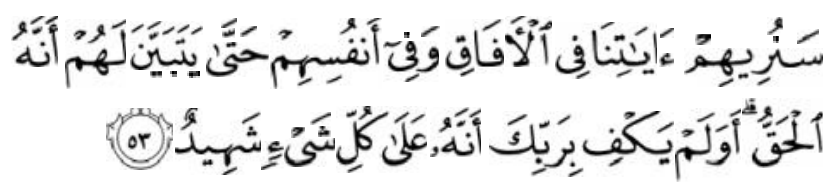

Artinya: Kami akan memperlihatkan kepada mereka tanda-tanda (kekuasaan) Kami di segala wilayah bumi dan pada diri mereka sendiri, hingga jelas bagi mereka bahwa al Quran itu adalah benar. Tiadakah cukup bahwa Sesungguhnya Tuhanmu menjadi saksi atas segala sesuatu?

Dimana untuk mengajarkan kitab-kitab klasik seorang kiai mengajarkan dengan menggunakan metode wetonan, sorogan dan hapalan, dan tidak mengenal sistem kelas. Menurut hemat penulis, metode yang diterapkan dipesatren dalam proses pembelajaran adalah membangun rasa keterbukaan antara kiai dan santri. Dalam hal ini santri tidak perlu merasa takut dan sungkan ketika menemukan pelajaran yang belum dipahaminnya. Oleh sebab itu yang dibangun dalam sistem pendidikan ini adalah rasa damai dan kasih sayang.

Yang harus dipahami, bahwa memberikan rasa aman disini adalah ketika memberikan penjelasan dan pemahaman materi pelajaran seorang guru (kiai) tanpa harus menggunakan kata-kata kasar dan ekspresi wajah marah. Oleh sebab itu, rasa damai akan muncul apabila pribadinya memiliki sikap dan prilaku yang muncul dari hati yang bersih (qalb salim). ${ }^{19}$ Ketika suasana pembelajaran yang dibangun dengan kondisi di atas, maka memudahkan peserta didik untuk meneri dan memahami pelajaran dengan baik.

${ }^{18}$ Baedhowi, Antropologi al-Qur'an, Yokyakarta: LKIS, 2009, hal. 183.

${ }^{19}$ Kata silm atau salima memiliki makna dasar selamat atau sentosa. Kata ini memiliki beberapa kata jadian, yaitu sallama (tenang yang dirasakan dihati) dengan varian sallamtum (membayar upah[kewajiban] yang harus dibayar), tusallimu/yusallimu/tusallimuna (memberi salam/menerima sepenuh hati sebuah keputusan yang diberikan oleh yang memiliki atau diberi otoritas), sallim (memberi salam), aslama, aslamtum, aslamna, aslamu, aslim (pasrah/berserah diri, beragama Islam), silm (masuk Islam), salam (perdamaian, berserikat), salim (sehat), salam (keselamat), salim (hati yang bersih), Islam (agama Islam), dan muslim (orang islam atau yang pasrah). Lihat lebih jelas Budhy Munawar-Rahman, Pendidikan Karakter: Pendidikan Menghidupkan Nilai untuk Pesantren, Madrasah dan Sekolah, The AsiaFoundation, cet III, 2017, hal. 7-8. 
Selain rasa damai, rasa kasih sayang/ cinta pun juga harus dibangun dalam proses belajar. Hal ini membuat suasana akan merasa tenang tanpa ada paksaan dalam memberikan penjelasan dan pemahaman kepada para santri. Karena menurut Budhy, ${ }^{20}$ cinta pada prinsinya menciptakan dan memelihara hubungan harmonis antara manusia dengan alam semesta. Selain itu, dengan cinta akan terjalinnya ukhuwah harus dilandasi dengan keikhlasan, kebaikan hati, kesetiaan, saling memahami, penuh pengertian dan tanggung jawab.

Suasana belajar mengajar di pesantren berlangsung sepanjang hari dan malam. Di mana posisi kiai juga berada dalam suasana mengajar, dan hubungan antara kiai dan santri sama halnya hubungan antara orang tua dan anak. Oleh sebab itu, penanaman akhlak sangat dipentingkan di pesantren. Akhlak sesama teman dijaga betul sehingga tidak timbul sengketa dan ukhuwah islamiah selalu terjaga, sedangkan akhlak kepada masyarakat sekitar harus dijaga agar citra pesantren tidak luntur di mata masyarakat. Terlebih-lebih akhlak kepada kiai sangat diutamakan, sebab dari kiailah santri memperoleh ilmu pengetahuan. Dikarenakan durhaka kepada kiai bisa berakibat tidak berkahnya ilmu. Jadi dalam kehidupan pesantren, penghormatan kepada kiai menempati posisi penting.

Sesuai dengan tujuan pesantren, ${ }^{21}$ sebagaimana yang dijelas Haidar $^{22}$ menyebutkan bahwa penekanan yang amat dipentingkan dalam menuntut ilmu adalah keikhlasan. Makna yang dijabarkan dari keikhlasan ini adalah menuntut ilmu, bukan untuk mencari pangkat dan kedudukan dan juga bukan untuk mencari harta. Oleh karena itu, ijazah dalam pengertian tanda lulus ujian akhir, yang dikeluarkan oleh pemerintah untuk dapat digunakan mencari pekerjaan, tidaklah begitu dipentingkan.

Pengaruh lain dari sikap yang dikemukakan di atas adalah: timbulnya semangat mandiri dan percaya diri yang tinggi. Santri dididik untuk tidak menggantungkan harapannya kepada ijazah, dan dengan tidak mempunyai mental pencari kerja, tetapi adalah bermentalkan pencipta kerja.

Inti dari sistem pendidikan yang dilaksankan di pesantren ialah mengajarkan ilmu agama dan sikap beragama. Dikarenakan mata pelajaran yang diajarkan semata-mata pelajaran agama. Sedangkan pada tahap awal Mahmud Yunus membagai ke dalam empat tingkatan yaitu: dasar, menengah, tinggi dan takhassus. Namun setelah datangnya kaum penjajah Barat (Belanda), peranan pesantren sebagai lembaga pendidikan Islam semakin kukuh. Pesantren merupakan

${ }^{20}$ Budhy Munawar-Rahman, Pendidikan Karakter, .........., hal. 125.

21 Menurut hasil penelitian Mastuhu, bahwa tujuan pendidikan di pesantren adalah menciptakan dan mengembangkan kepribadian muslim, yaitu kepribadian yang beriman dan bertaqwa kepada Tuhan, berakhlak mulia, bermanfaat bagi masyarakat atau berkhidmat kepada masyarakat dengan jalan menjadi kawula atau mengabdi kepada masyarakat seperti Rasul, yaitu menjadi pelayan masyarakat sebagaimana kepribadian Nabi Muhammad (mengikuti sunah Nabi), mampu berdiri sendiri, bebas dan tegas dalam pendirian, menyebarkan agama atau menegakkan Islam dan kejayaan umat Islam di tengah-tenngah masyarakat ('izzul Islam wal muslim) dan mencintai ilmu dalam rangka mengembangkan kepribadian bangsa Indonesia. Mastuhu, 1990, hal. 148.

22 Haidar Putra Daulay, Sejarah Pertumbuhan dan Pembaruan Pendidikan Islam di Indonesia, Jakarta: Kencana, cet ke. 4, 2014, hal. 71. 
lembaga pendidikan Islam yang reaksional terhadap penjajah. Karena itu, di zaman Belanda pendidikan di pesantren dibandingkan pendidikan sekolah-sekolah umum. Pesantren semata-mata mengajarkan ilmu-ilmu agama lewat kitab-kitab klasik, sedangkan sekolah umum Belanda sama sekali tidak mengajarkan pendidikan agama. Sistem pendidikan pesantren baik metode, sarana fasilitas, serta yang lainnya masih bersifat tradisional.

Namun dalam perkembangan berikutnya, pesantren mengalami dinamika, kemampuan dan kesediaan pesantren untuk mengadopsi nilai-nilai baru akibat modernisasi, menjadikan pesantren berkembang dari yang tradisional ke modern. $\mathrm{Hal}$ ini dapat dilihat dari sistem klasikal yang dipakai, memasukkan materi umum dalam materi pelajaran serta pemberian ijazah kepada para lulusannya. Menurut Nurkholish Madjid, ${ }^{23}$ bahwa dalam perkembangan selanjutnya pesantren melakukan akomodasi dan konsesi tertentu untuk kemudian melakukan pola yang dipandangnya cukup tepat dalam menghadapi modernisasi dan perubahan yang kian cepat dan berdampak luas.

Perubahan-perubahan yang dilakukan dalam pola pendidikan di pesantren menurut Abdurrahman Wahid antara lain: pertama, keinginan sangat kuat pada permulaan abad ke-20 untuk menerapkan sistem sekolah pada pendidikan di pesantren yang dimulai beberapa pesantren di Sumatra dan Tebuireng Jombang; kedua, pergeseran secara halus tujuan pendidikan di pesantren dari penciptaan pengertian merata tentang ilmu-ilmu pengetahuan agama berubah menjadi pendalaman ilmu-ilmu pengetahuan agama untuk dijadikan sebagai landasan menempuh karir tertentu yang umumnya sebagai tenaga pengajar agama. Akibatnya, semakin kuatnya keinginan untuk menciptakan tenaga-tenaga elit dalam ilmu keagamaan di beberapa negeri pada madrasah yang mereka miliki. ${ }^{24}$

Lebih lanjut Abdurrahman Wahid menjelaskan bahwa, dari perubahan pola pendidikan yang terjadi di pesantren, mengakibatkan sistem pendidikan pesantren mengalami krisis identitas. Di satu pihak, pesantren tetap memiliki watak populisnya lantaran elastisnya program pendidikan individu minimal dalam pendidikan ekstrakurikuler yang berbentuk pengajian; Di pihak lain, kecenderungan untuk menumbuhkan pendidikan berwatak elitis juga berjalan cukup kuat. Krisis identitas ini menurut beliau, sebagai akibat dari kesulitan mendamaikan kedua watak yang saling bertentangan hingga kini belum teratasi. ${ }^{25}$

Melihat dari respon pesantren dalam menghadapi perubahan-peruban akibat arus dan gelombang modernisasi, khususnya dalam model sekolah Barat (sekuler), maka Mujamil Qomar membuat catatan untuk menjelaskan arah baru kehidupan pesantren antara lain:

1. Perubahan yang ditempuh pesantren tidak menghapus tradisi yang lama, tetapi sekedar menambah dengan sesuatu yang baru sehingga tradisi

${ }^{23}$ Nurkholis Madjid, Bilik-Bilik Pesantren; Sebuah Potret Perjalanan, Jakarta: Mizan, 2997, hal. XXV.

${ }^{24}$ Abdurrahman Wahid, Bunga Rampai Pesantren, CV. Dharma Bhakti, tt, hal. 102-103.

${ }^{25}$ Ibid, hal. 103-104. 
maupun kondisi yang lama bisa dipertahankan sambil menerima kehadiran yang baru.

2. Cara menempuh perubahan ini memang tidak menimbulkan resistensi yang kuat dari kalangan internal pesantren, tetapi menimbulkan krisis identitas karena belum berhasil mendamaikan kondisi atau tradisi yang lama dengan yang baru, sedangkan masing-masing kondisi atau tradisi itu memiliki watak yang berlawanan.

3. Krisis identitas itu mengakibatkan pesantren sikap mengahadapi modernisasi menjadi tidak jelas bahkan ambivalen sebagaimana dilukiskan Steenbrink sebagi suatu sikap yang "menolak sambil mengikuti", suatu sikap yang aneh. Secara praktis sikap ini bisa diterapkan tetapi secara psikis menjadi beban moral.

4. Respon pesantren terhadap gelombang modernisasi tidak dilandasi pertimbangan ilmiah (rasional dan kenyataan empiris) yang matang, tetapi lebih mempertimbangkan faktor politis, emosi, dan rasa fanatik sehingga pendirian pesantren menjali labil atau mudah berubah-rubah dalam garis yang zig-zag.

5. Respon pesantren terhadap gelombang modernisasi itu lebih memperkuat kecondongan pada penguatan orientasi ekonomi dan serba perhitungan materi seperti masuknya sekolah dan perguruan tinggi, pembentukan tenaga pengajar agama, perubahan status madrasah menjadi negeri, dan pendidikan dengan uang. ${ }^{26}$

Namun itu semua tidak merubah kekhasan yang dimiliki oleh pesantren dalam sistem pendidikannya yaitu tafaqquh fi al- din. Walaupun kondisi yang terjadi akhir-akhir ini di negara kita menyebabkan posisi pesantren menjadi sorotan masyarakat. Hal ini dikaitkan bahwa "sebagian pesantren" ada yang mengajarkan "paham-paham radikalisme". Namun kondisi ini tidak akan pernah menyurutkan para santri dan kiai dalam mengembangkan ilmu pengetahuan, karena pada hakekatnya budaya yang terjalin dipesantren merupakan cerminan dari budaya berbangsa dan bernegara kita.

\section{Pendidikan Pesantren dalam menerapkan nilai-nilai karakter Berbangsa dan Bernegara}

Pendidikan karakter yang didengung-dengungkan Kemendiknas pada saat ini, jauh sebelumnya Ki Hadjar Dewantara sudah membahasnya secara tuntas dalam kedua karya monumentalnya yaitu: Pendidikan dan kebudayaan. Dalam pemikiran Beliau pendidikan karakter merupakan istilah dari Pendidikan Budi Pekerti. Namun Jauh sebelumnya, Islam pun sudah menerangkan akan pentingnya dari Pendidikan karakter. Hal ini dibuktikan dalam Q.S: al-Qolm:4:

\footnotetext{
${ }^{26}$ Mujamil Qomar, Menggagas Pendidikan Islam, Bandung: Rosdakarya, 2014, hal. 8-9.
} 


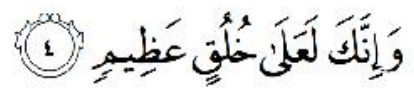

Artinya: "dan Sesungguhnya kamu benar-benar berbudi pekerti yang agung."

Selain itu, tujuan Allah mengutus Nabi Muhammad untuk menyempurnakan menyempurnakan aklak manusia.

Akan tetapi model pendidikan karakter yang dicanangkan Kemendiknas menurut Zuhdi sebagaimana yang dikutib oleh Suyadi, berkiblat kepada Thomas Likona, ${ }^{27}$ dengan alasan bahwa ia merupakan tokoh pertama yang mengenalkan pendidikan karakter. ${ }^{28}$ Namun pendidikan karakter yang diterapkan di pondok pesantren, menurut KH. Abdullah Syukri Zarkasi (Pimpinan Pondik Modern Gontor) sebagai salah satu sub sistem pendidikan nasional yang indigenous Indonesia. Yang mempunyai keunggulan dan karakter khusus dalam mengaplikasikan pendidikan karakter bagi anak didiknya (santri). Hal ini dikarenakan bahwa di pondok memiliki jiwa dan falsafah. Jiwa dan falsafah yang ditanamkan kepada anak didiknya (santri) inilah yanng akan menjamin kelangsungan sebuah lembaga pendidikan bahkan menjadi motor penggerak menuju kemajuan di masa depan. ${ }^{29}$

Perkataan etika, moral atau budi pekerti menurut KH. Imam Zarkasyi sangatlah umum, sehingga pelajaran tentang etika mengandung banyak hal yang saling berhubungan. Sebab menurut beliau, etika atau budi pekerti tidak lain ialah ilmu bertindak atau pengetahuan tentang hal-hal yang menunjukkan kepada kita jalan yang baik untuk dapat hidup dalam masyarakat. Lebih lanjut beliau menjelaskan bahwa etika sangat erat hubungannya dengan agama, sedangkan agama mengandung beberapa anasir yang boleh diringkas dalam tiga macam, yaitu:

1. Unsur kepercayaan (i'tiqad),

2. Unsur budi pekerti yang berhubungan dengan pekerjaan atau perangai (akhlaq),

3. Unsur perasaan (sentimen, 'atifah).

27 Istilah pendiidkan karakter mulai dikenalkan sejak tahun 1900-an. Thomas Likona disebut-sebut sebagai pengusungnya, terutama ketika ia menulis buku yang berjudul The Return of Character Education, yang kemudian disusul buku berikutnya Educatinng for Character. How Our School Can Teach Respectand Responsibility. Menurutnya pendidikan karakter mencakup tiga unsur pokok, yaitu mengetahui kebaikan (Knowing the good), mencintai kebaikan (Desirinng the good), dan melakukan kebaikan (doing the good).

${ }^{28}$ Suyadi, Strategi Pembelajaran Pendidikan Karakter, Bnandung: Remaja Rosdakarya, 2013, hal. 3. ${ }^{29} \mathrm{http}$ ://iprafuns.blogspot.co.id/2010/02/peran-pesantren-dalam-pendidikan.html di akses tgl 21 juli 2017. 
Dalam tulisan ini, penulis ingin menggambarkan Pondok Modern Gontor sebagai salah satu pondok modern yang memiliki panca jiwa pondok. Tradisi ini bahkan diikuti hampir keseluruhan pesantren yang ada di Indonesia. Bahkan Panca jiwa Pondok Gontor juga diterapkan sebagai jiwa dan falsafah di pondok lainnya di Indonesia.

Adapun panca jiwa pondok Gontor yang diterapkan yaitu: ${ }^{30}$

1. Keikhlasan

2. Keserdehanaan

3. Kemandirian

4. Ukhuwah Islamiyah

5. Kebebasan.

Jiwa keikhlasan yang digambarkan oleh pondok, menurut KH. Imam Zarkasyi merupakan anak tangga yang pertama dan utama yang akan membawa para penghuni pesantren memperoleh kemudahan untuk menjadi insan yang taqwa. Keikhlasan pula yang menjadikan dasar dalam setiap gerak perjuangan dalam menjalankan kehidupan di dunia. Melihat dari jiwa keikhlasan yang ditamankan dipesantren, menjadikan dasar bagi kita untuk membangun bangsa dan negara mulai dari tingkat terendah sampai yang tertinggi. Tanpa harus melihat ras, golongan, suku, agama sampai politik sekalipun. Karena jika dasar di atas tidak dikembangkan dalam membangun bangsa dan negara kita, maka akan terjadi kesenjangan dalam segala aspek karena melihat kepentingan dan hajat masingmasing.

Jiwa kesederhanaan bukan berarti bersikap pasif (narimo) atas keadaan atau nasib yang tidak dikehendaki. Bersikap sederhana bukanlah ditunjukkan dengan kondisi kemelaratan atau kemiskinan yang dihadapi, namun mengandung unsur kekuatan dan ketabahan hati, sikap berani maju terus dalam dalam menghadapi berbagai problem sebagai konsekwensi perjuangan hidup, sehingga dalam benak muncul sikap pantang mundur dalam berbagai kesulitan yang ada, betapapun pahit keadaan yang dihadapinya.

Jiwa kesanggupan menolong diri sendiri/ kemandirian (self help), bukan saja dalam arti bahwa santri selalu belajar dan berlatih mengurus segala macam kepentingannya sendiri, tanpa bergantung kepada orang lain. Jika jiwa kemandirian ini di terapkan dinegara kita yang memiliki kekayaan alam yang melimpah dan dapat mengelola dan memanfaatkan untuk rakyat sendiri tanpa harus bergantung pada negara lain, tentu saja tidak akan terjadi ketimpangan baik dari segi sosial, ekonomi.

Jiwa Ukhuwah Islamiyah di pondok tercermin dalam suasana demokrasi antara para santri yang ada dalam pesantren yang akrab sehingga segala

${ }^{30}$ Untuk lebih jelas makna yang terkandung dalam Paca Jiwa Pondok, baca Amir Amir Hamzah Wiryosukarto, et al, Biografi K.H. Imam Zarkasyi dari Gontor Merintis Pesantren Modern, Ponorogo: Gontor Press, 1996, cet. Ke-1

Hamzah Wiryosukato at al, K.H. Imam Zarkasyi Di Mata Umat, Riwayat Hidup dan Perjuangan K.H. Imam Zarkasyi Pondok Modern Gontor Ponorogo, Gontor Press, 1996, hal. 882884. 
kesenangan, lebih-lebih kesedihan, dirasakan bersama dalam suasana keagamaan yang utuh dan menyeluruh. Jiwa Ukhuwah Islamiah ini tidak hanya dikembangkan selama berada di pondok pesantren, namun semangat ini tetap dipelihara dengan baik setelah para santri berada di masyarakat. Dengan demikian dapat diharapkan mereka akan mampu melahirkan suasana persatuan di kalangan umat Islam, dan bangsa Indonesia secara keseluruhan. Melihat jiwa yang dikembangkan ini, maka menjadi suatu keniscayaan bagi bangsa Indonesia yang memiliki berbagaimacan golongan, ras, suku dan agama. Namun, rasa kebersamaan dan saling menghargai seakan menjadi "barang mahal" yang harus dirasakan saat ini. Rasa saling curiga, saling menghujat bahkan muncul slogan "intoleran" yang akan memicu berdebatan bahkan kehancuran bangsa ini. Namun jika di pahami sebagai bangsa yang besar terdiri dari beribu-ribu pulau yang terhampar dari sabang sampai merauke, maka perbedaan ras, suku dan agama tidaklah menjadi suatu halangan bagi rakyat Indonesia untuk hidup damai dan tentram. Karena pada hakekatnya bangsa Indonesia sebagai bangsa yang besar diikat dengan Bhenika Tunggal Ika, untuk menjaga keutuhan Negara Kesatuan Republik Indonesia.

Jiwa kebebasan ditumbuhkan dalam berfikir dan berbuat selama santri dalam pendidikan, agar kelak mereka bebas pula menentukan masa depannya dalam memilih jalan hidup di masyarakat. Dengan berjiwa besar dan optimis, para santri akan memperoleh kemudahan dalam menghadapi berbagai kesukaran yang ada dalam kehidupan dunia ini.

Jika jiwa kebebasan diterapkan dalam kehidupan berbangsa dan bernegara, adalah bebas dalam menentukan dan mengeluarkan pendapat sesuai dengan koridor yang telah ditentukan. Tanpa harus menyalahkan dan menyudutkan pihak lain serta mementingkan kehendakk pribadi dan golongan tertentu.

Oleh karena itu, jika dihayati sistem pendidikan yang dilaksanakan di pondok pesantren dengan panca jiwa yang menjadi dasar kehidupan di pesantren, jika tidak berlebihan sangatlah tepat bila di terapkan dalam bersosialisai bagi bangsa dan negara Indonesia.

\section{Kesimpulan}

Pondok pesantren sebagai lembaga pendidikan tertua dan asli Indonesia, hingga saat ini hampir ribuan jumlahnya tersebar keseluruh wilayah Indonesia. Walaupun menghadapi modernisasi pesantren mengalami "perubahan" dalam sistem pendidikannya. Namun perubahan ini tidak memudarkan kecirikhasan pondok pesantren. Karena unsur di dalamnya yang terdiri dari kiai, santri, kitab kuning serta masjid yang menjadi sentral pendidikannya sangat mengakar dalam sistem pendidikannya. Serta dalam menjalani kehidupan di pensantren ada panca jiwa yang mendasari pelaksanaannya. Sehingga terjalin keakraban, saling menghormati dan menghargai antara penghuni di dalamnya. 


\section{Daftar Pustaka}

Al-Qur'an dan terjemahan RI

Ali Syari'ati, Tentang Sosiologi Islam, Yokyakarta: Ananda, 1982, Terj. Saifullah Mahyuddin

Amir Hamzah Wiryosukarto, et al, Biografi K.H. Imam Zarkasyi dari Gontor Merintis Pesantren Modern, Ponorogo: Gontor Press, 1996, cet. Ke-1

Abdurrahman Wahid, Bunga Rampai Pesantren, CV. Dharma Bhakti, tt

Baedhowi, Antropologi al-Qur'an, Yokyakarta: LKIS, 2009

Budhy Munawar-Rahman, Pendidikan Karakter: Pendidikan Menghidupkan Nilai untuk Pesantren, Madrasah dan Sekolah, The AsiaFoundation, cet III, 2017

Hanun Asrohah, Sejarah Pendidikan Islam, Jakarta: Logos, 1999.

Harun Nasution, Teologi Nasution, Aliran-aliran, Sejarah, Analisa Perbandingan, Jakarta: UI Press, 1983

Husen Hasan Basri, Makalah, "Kapasitas dan Tawaran "Tipologi Baru" Pesantren, disampaikan dalam acara Wokrshop Pengembangan Pemikiran Keagamaan di Pesantren, di Aston Pangkalpinang pada tanggal 9-11 November 2016.

Haidar Putra Daulay, Sejarah Pertumbuhan dan Pembaruan Pendidikan Islam di Indonesia, Jakarta: Kencana, cet ke. 4, 2014

http://iprafuns.blogspot.co.id/2010/02/peran-pesantren-dalam-pendidikan.html $\quad d i$ akses tgl 21 juli 2017

Imam Zarkasyi dan Ahmad Sahal, Wasiat, Pesan dan Harapan, Pendiri Pondok Modern Gontor, $\mathrm{tt}$

Ismail Sm dkk (ed), Dinamika Pesantren dan Madrasah, Yokyakarta: Pustaka Pelajar, 2002, p.xix.

M. Amien Rais, Cakrawala Islam, Antara Cita dan Fakta, Bandung: Mizan, 1989

M. Din Syamsuddin, Etika Agama dalam membangun Masyarakat Madani, Jakarta: Logos Wacana Ilmu dan Pemikiran, 2000

Mastuhu, Dinamika Sistem Pendidikan Pesantren, Jakarta: INIS, 1994

Mujamil Qomar, Menggagas Pendidikan Islam, Bandung: Rosdakarya, 2014

Nurkholis Madjid, Bilik-Bilik Pesantren; Sebuah Potret Perjalanan, Jakarta: Mizan, 2997

Ramayulis, Ilmu Pendidikan Islam, Jakarta: Kalam Mulia, cet. X 2013

Rusydi Sulaiman, Falsafah dan Idealisme Pesantren, Upaya Merevitalisasi kelembagaan Pondok Pesantren, Makalah disampaikan pada acara Workshop Pemgembangan Pemikiran keagamaan di Pessantren, tanggal 9-11 November 2016 di Aston Bangka Belitung.

Suwito dan Fauzan (ed), Sejarah Sosial Pendidikan Islam, Jakarta: Kencana, 2005

Silfia Hanani, Makalah, Surau Representasi Pondok Pesantren Tradisional dalam Membangun Intelektualitas di Minangkabau, dalam acara Wokrshop 
|SOLEHA| Sistem Pendidikan Pesantren Dalam Membangun...

Pengembangan Pemikiran Keagamaan di Pesantren, di Aston Pangkalpinang pada tanggal 9-11 November 2016.

Suyadi, Strategi Pembelajaran Pendidikan Karakter, Bandung: Remaja Rosdakarya, 2013

Zamakhsyari Dhofier, Tradisi Pesantren: Studi tentang Pandangan Hidup Kiai, Jakarta: LP3ES, 1982 